tion such as the use of memos and interviews, public relations, public hearings and how to plan and carry out a successful action campaign.

Guidelines for Meeting with Legislators, Pub. No. 21-1640; Guidelines for Writing to Your Congressman, Pub. No. 21-1641; Guidelines for Presenting Testimony on Legislation, Pub. No. 21-1642 (1976). National League for Nursing, Ten Columbus Circle, New York, NY 10019, \$.25 each, plus handling. This series of three Government Relations Pamphlets published by the National League for Nursing provide excellent checklists of do's and don'ts with some elaboration on each point.

The Library Lobbyist (1977). New York Library Association, 15 Park Row, Suite 434, New York, NY 10018, \$.75. This booklet is designed to be a practical guide for librarians, trustees and patrons working with the New York State Legislature and other levels of government.

Tell It to Washington: A Guide for Citizen Action Including Congressional Directory 1981-82, Pub. No. 349 (March 1981). League of Women Voters of the United States, 1730 M Street, N.W., Washington, DC 20036. \$1.00. Tell It to Washington includes a congressional directory, a list of congressional committees and their members, information on the legislative and budget processes and tips on writing to and visiting legislators.

Contact the League of Women Voters for their list of publications on local and national government.

Editor's Note: This article was originally published in the November-December 1981 issue of the MLA News.

\title{
Academic Libraries Frontier Conference
}

\section{FROM THE EXECUTIVE DIRECTOR:}

In December, forty-nine people with major responsibilities in management of academic research libraries, and their counterparts in library education, participated in the Academic Libraries Frontier Conference for 1981. Funded by the Council on Library Resources and planned by Robert Hayes, dean of the Graduate School of Library and Information Science at UCLA, the group met with the objective of identifying issues of mutual concern. The agenda included:

- What are the issues of importance?

- If they represent problems, are there evident means for solution of them?

- What research may be needed to provide the data needed for future decisions concerning the issues?

- What are the requirements for education that will provide upcoming generations with the knowledge and skills needed to deal with the issues?

Six commissioned papers were presented during the morning sessions, as a backdrop for the small working groups and informal evening sessions. William Gerberding, president of the University of Washington, spoke on the experience of retrenchment. He cautioned the group: "If you are going to get through the next period you are going to have to do it alone because presidents don't have a future view that will be helpful."

Jerald Stevens, the vice-president for finance at Yale, speculated on the economic environment over the next twenty years. He predicts that a lower rate of growth will make the U.S. economy unable to absorb the social programs of the past and that education will be unable to maintain its share of the economy. He anticipates that student demand will govern trends in higher education with a shift to vocational education. There will be a reduction in scholarly output, an impulse to centralize educational systems and libraries, and libraries may become an entry point for contractual services in educational institutions. Other papers by William Schaefer, Howard Resnikoff, and John Brademas dealt with the student population, information technologies, and the political environment, respectively.

The concluding paper by Steven Muller, president of Johns Hopkins University, provided a provocative view of the library's future, wherein the university will have at its heart a communications center. The question posed was where will that communications center be? Can the library expand to be the information center of the university? The university will need to have a computing service that does more than research and serve the administration. Whether the library or the computer center will serve as the communications/information center will depend on which one outperforms in service.

The ideas from the work groups will be synthesized and included in the proceedings of the conference. Edited by Robert Hayes, the publication will appear this year. As Dick Dougherty said in summing up the conference, "At this point we don't know how successful the conference waswhether we approached the frontiers or crossed them." Certainly it was a unique gathering of library administrators and library educators.Julie Carroll Virgo. 


\section{You can save $\$ 6,000$ this year}

By converting your subscription to the British House of Commons Parliamentary Papers for 1981/82 from the full size edition (which is costing you over $\$ 7,000$ ) to our microfiche edition which costs $\$ 1,400$.

Save time. The microfiche edition is sent monthly by airmail direct from the UK and arrives earlier than the printed edition.

Save space. The mcrofiche edition saves expensive shelf space.

Many large libraries have released substantial funds for other purchases by converting to the microfiche edition. So can you - to make the maximum saving this year please send us your order or request for more information as soon as possible.

\section{Catalogue of British Official Publications}

\section{Not published by HMSO \\ 1980 Annual Volume \$190 \\ 1981 Six Bi-monthly Issues and Annual Cumulation \$260}

This important new reference book catalogs and indexes for the first time the thousands of official publications published by over 300 Government departments, nationalised industries, research institutes and 'quangos' that are not published by HMSO, and are not listed in the British National Bibliography or any other bibliography.

You will now have access to publications of institutions such as the Foreign Office, the Home Office, and the Bank of England.

The publications themselves are available from us on inexpensive diazo or silver microfiche; individually, by publishing body, or in subject sets.

Send orders and requests for information to:

Somerset House, 417 Maitland Avenue, Teaneck, NJ 07666

Telephone: 201 833-1795 